\title{
Random Drug Testing of Government Employees: A Constitutional Procedure
}

\author{
Edward S. Adams $\dagger$
}

\begin{abstract}
Even the war on crime must be fought by constitutional methods for the Constitution protects the guilty as well as the innocent and proscribes condemned means even when they are used for laudable ends.'
\end{abstract}

On July 30, 1986, President Reagan first hinted that a major policy initiative was underway to curb drug use within the ranks of federal government. ${ }^{2}$ Two and one half months later, the President signed an executive order to initiate drug testing for a broad range of the federal government's 2.8 million civilian employees. The President earmarked approximately $\$ 56$ million for the first year of the program. ${ }^{3}$

Government employee drug testing prompts numerous legal considerations. The paramount question, however, is whether random government drug testing of its employees is permissible under the fourth amendment of the United States Constitution. The answer to that question is yes: random drug testing of government employees is entirely consistent with fourth amendment guarantees if the government observes certain constitutional safeguards.

Part I of this comment considers the societal effects of drug use, the purposes of drug testing, and the effectiveness of such tests. Part II proposes a random drug testing procedure that passes

$\dagger$ B.A. 1985, Knox College; J.D. Candidate 1988, The University of Chicago.

National Treasury Employees Union v. Raab, 816 F.2d 170, 173 (5th Cir. 1987). The $R a a b$ court upheld a random urinalysis program incorporating procedural safeguards.

${ }^{2}$ Irving R. Kaufman, The Battle Over Drug Testing, The New York Times Magazine 52 (Oct. 19, 1986). President Reagan announced he was considering both widespread testing of government employees and extension of then existing procedures of agencies such as the Federal Bureau of Investigation, the Immigration and Naturalization Service, the Federal Aviation Administration, the Postal Service, the Drug Enforcement Administration, and the military services. Id.

${ }^{3} 3$ C.F.R. $\S$ EO 12,564 (1987). See also Kaufman, N.Y.T.Mag. at 52 (cited in note 2). This program is not the first indication of the federal government's concern over drug use. Courts have permitted drug tests in the military. See, e.g., Committee for GI Rights v. Callaway, 518 F.2d 466, 469 n.10 (D.C.Cir. 1975). Similarly, administrative agencies have enacted regulations regarding drug testing. See, e.g., 14 C.F.R. $\$ 91.12$ (1973)(Federal Aviation Commission ban on controlled substances on planes); 49 C.F.R. $\$ 391.41$ (1985)(Department of Transportation regulations on interstate truck drivers); 49 C.F.R. $\S 219$ (1986)(Federal Railroad Administration regulations). 
fourth amendment scrutiny, ${ }^{4}$ as later parts of this comment demonstrate. With this comment's model testing procedure as a focal point, Part III examines the fourth amendment issues implicated by random drug testing of government employees, and demonstrates that the fourth amendment does not bar all random testing. Finally, Part IV moves beyond the fourth amendment and illustrates that the procedure for employee evaluation and termination implemented by the Drug Testing Proposal of Part II complies with due process requirements.

\author{
I. The Costs of Drug Use, \\ the Purpose of Drug Testing, \\ and THe Effectiveness of DRUg Tests
}

The effects of drug use on American society are great. The $\$ 27$ billion to $\$ 110$ billion in estimated narcotics traffic each year fuels and contributes to crime. ${ }^{5}$ Industrial costs of drug abuse are monu-

- Although this comment deals principally with fourth amendment problems, other types of substantive constitutional attacks have been made on government drug testing programs involving urinalysis. For example, at first glance, a requirement that government employees submit to urinalyses that may later be used against them appears analogous to testimonial compulsion barred by the fifth amendment right against self-incrimination. Courts, however, have repeatedly held that the fifth amendment does not apply to situations or acts apart from an individual's communications or testimony. Compulsions that make the accused the source of real or physical evidence do not violate the fifth amendment. In Schmerber v. California, 384 U.S. 757, 764-65 (1967), the Supreme Court ruled that blood tests were physical evidence and thus not subject to fifth amendment immunity. Other forms of evidence in this category include fingerprints, photographs, writings or speech for identification, appearances in court, standing, walking, or particular gestures used for identification. Id. Courts have uniformly held that urine samples fall into this category. See, e.g., Raab, 816 F.2d at 181 .

A stronger argument contends that drug testing through urinalysis infringes upon a federal government employee's constitutional right to privacy. Resolution of this issue is difficult and beyond the scope of this comment. Some of the privacy cases argue, however, that mandatory drug testing through urinalysis does not violate the employee's right to privacy. These cases hold that the Constitution recognizes an individual's right to privacy only in areas "relating to marriage, procreation, contraception, family relationships and childbearing." Paul v. Davis, 424 U.S. 693, 713 (1976). A court reading the privacy cases broadly, however, might argue that the Constitution prohibits the government from engaging in regulation that threatens to expose activities done in the privacy of an individual's home. See Griswold v. Connecticut, 381 U.S. 479, 484 (1965). Alternatively, a court might argue that the constitutional right to privacy prohibits the government from making widespread use of urinalysis test results. See, e.g., Whalen v. Roe, 429 U.S. 589, 606 (Brennan concurring) ("[broad] dissemination by state officials of such information [as drug prescriptions] . . . would clearly implicate constitutionally protected privacy rights, and would presumably be justified only by compelling state interests").

s Evan Thomas, America's Crusade, Time 60, 63 (Sept. 1, 1986). In a study released in 1986, concentrating on suspects in New York and Washington, 56 percent of the suspects tested were under the influence of drugs at the time of their arrest. Id. 
mental. "In human terms they include lost jobs, injuries, illnesses, and deaths. In economic terms they include property damage, tardiness, absenteeism, lost productivity, quality control problems, increased health insurance costs, increased worker's compensation costs, the cost of replacing and training new employees, and employee theft." 6 Government estimates suggest that drug abuse cost employers in the United States $\$ 33$ billion in $1985 .^{7}$

Proponents envision drug testing as a partial solution to the use of illegal drugs and the consequences of such use on American society. Evidence indicates that for many businesses drug testing has reduced the number of employee accidents while increasing worker productivity. ${ }^{8}$ Already, numerous private employers utilize random urinalysis in order to detect drug abuse. For example, IBM, DuPont, Exxon, Lockheed, Shearson Lehman Brothers, Federal Express, United Airlines, Trans World Airlines, AT\&T, and the New York Times have instituted random drug testing programs for job applicants. Other businesses have begun to test not just applicants, but also existing employees, for drug use. Two Wall Street firms, Kidder, Peabody \& Company and Smith Barney, Harris, Upham \& Company, recently became the first brokerage houses to check employees for the use of illegal drugs. ${ }^{8}$ Finally, about 25 percent of the Fortune 500 companies currently perform drug screening, a sharp rise from three years ago, when only 10 percent of these employers maintained testing programs. ${ }^{10}$

Opponents of drug testing argue that drug testing is inaccurate; some claim that drug tests yield inaccurate results up to 67

- Thomas E. Geidt, Drug and Alcohol Abuse in the Work Place: Balancing Employer and Employee Rights, 11 Emp.Rel.L.J. 181, 184 (1986).

7 Thomas, Time at 63 (cited in note 5). Some estimates suggest that the cost to industry of drug abuse ranges from $\$ 50$ billion to $\$ 100$ billion annually due to increased health care cost and lost productivity. David J. Hanson, Drug Abuse Testing Programs Gaining Acceptance in the Workplace, Chem. \& Eng. News ("C\&EN") 7, 8 (June 2, 1986).

8 After the Georgia Power Company implemented a drug testing program, the number of accidents decreased from 5.4 injuries per 200,000 man hours to less than 0.5 per 200,000 man hours. Robert Angarola, Mandatory Drug Testing in the Workplace: Protect Safety, Not Drug Abuse, A.B.A.J. 35 (Aug. 1986). Southern Pacific Railroad had similar results with its program, reporting a 71 percent drop in on-the-job accidents and injuries due to humanrelated error as compared to the previous year. Id.

- Kaufman, N.Y.T.Mag. at 53 (cited in note 2).

${ }^{10}$ Mark A. Rothstein, Screening Workers for Drugs: A Legal and Ethical Framework, 11 Emp.Rel.J. 422, 423 (1986). A recent survey indicates an additional 20 percent of Fortune 500 employers plan to institute such programs in two years. See Noel Dunivant \& Associates, Drug Testing in Major U.S. Corporations: A Survey of the Fortune 500 (1985) (available from Noel Dunivant \& Associates, Raleigh, N.C.). 
percent of the time. ${ }^{11}$ Alternatively, opponents argue that even if tests are highly accurate, the tests nonetheless will harm innocent parties because they will produce false positives in some instances. ${ }^{12}$ Such criticism, however, is speculative at best. "Some claim [c] hemical testing. . .can be as close to $100 \%$ reliable as science permits." 13 The manufacturer of the most popular screening test, EMIT (Enzyme Multiplied Immunoassay Technique), claims an accuracy rate of better than 95 percent, ${ }^{14}$ while GC (gas chromatography) tests are even more accurate. ${ }^{15}$ Additionally, a study conducted by the United States Navy indicated that in 18,000 tests administered during the period from 1982-1985, not a single false positive was reported. ${ }^{16}$ Moreover, even if the drug tests are slightly inaccurate that does not mean that society should regard

12 Hanson, C\&EN at 10 (cited in note 7). See also Hugh J. Hansen, Samuel P. Caudill \& D. Joe Boone, Crisis in Drug Testing, 253 J.A.M.A. 2382 (1985)(tests 60 percent inaccurate); Centers for Disease Control, Urine Testing for Detection of Marijuana Use: An Advisory, 32 Morbidity \& Mortality Weekly Rep. 469 (1983) (tests 4 percent inaccurate).

Five basic types of drug testing exist: the enzyme multiplied immunoassay test (EMIT), the radioimmunoassays test (RIA), the gas chromatography test (GC), the mass spectrometer test (MS) and the thin layer chromatography test (TLC). See Lee I. Dogoloff \& Robert T. Angarola, Urine Testing in the Workplace 18-20 (The American Council for Drug Education ed. 1985) ("Dogoloff, Urine Testing"). See also Comment, Admissibility of Biochemical Urinalysis for the Purpose of Detecting Marijuana Use, 20 Wake Forest L.Rev. 391 (1984); Philip J. Bigger, Urinalysis: Issues and Applications, 43 Fed. Probation 23 (1979)(examining merits of certain drug testing methods). Employers commonly use EMIT and RIA tests as initial screening tests. Dogoloff, Urine Testing at 20. While the employer may conduct EMIT tests in the laboratory or workplace, John P. Morgan, Problems of Mass Urine Screening for Misused Drugs, 16 J. Psychoactive Drugs 305, 306 (1984), GC and RIA tests are restricted to a laboratory setting. Dogoloff, Urine Testing at 21. Employers commonly use GC or MS tests to confirm positive EMIT or RIA results. Richard H. Schwartz \& Richard L. Hawks, Laboratory Detection for Marijuana Use, 254 J.A.M.A. 788, 790 (Aug. 1985). Moreover, while it costs an employer only $\$ 5$ to conduct EMIT or RIA tests, Robert Lewy, Preemployment Qualitative Urine Toxicology Screening, 25 J. Occup. Med. 579, 580 (1983), the costs of GC or MS tests are \$25-35. Dunivant, Drug Testing at 4 (cited in note 10).

12 Consider if an employer uses a drug test where one in every 20 tests results in a false positive to screen a large number of employees. Assuming less than one percent of these employees has actually used drugs, this "accurate" test will falsely accuse five employees for every true accusation.

${ }^{13}$ Hanson, C\&EN at 8 (cited in note 7) (quoting Robert E. Willette, former Head of the Research Technology Branch at the National Institute of Drug Abuse and currently a director at Duo Research, a consulting company specializing in lab inspection and the monitoring of lab performance).

"Kaufman, N.Y.T.Mag. at 59 (cited in note 2). Courts have accepted EMIT test results as 95 percent accurate. See, e.g., Lovvorn v. City of Chattanooga, Tenn., 647 F.Supp. 875, 877 (E.D.Tenn. 1986).

${ }^{16}$ Thomas P. Moyer, Michael H. Palmen, et al., Marijuana Testing-How Good is It? 62 Mayo Clinic Proc. 413, 417 (1987) (reporting that the EMIT procedure using GC/MS provides "virtually $100 \%$ accuracy in the detection of marijuana abuse").

${ }^{16}$ Hanson, C\&EN, at 8 (cited in note 7 ). 
drug testing as fundamentally unfair - even courts of law do not require methods of perfect accuracy in reaching their decisions. ${ }^{17}$

In addition to questions regarding accuracy, other problems with drug testing do exist. First, no test can establish whether a subject is under the influence of a drug at the time the test is administered. ${ }^{18}$ Second, the tests are incapable of determining if and how much drug use impairs a given individual's level of performance. ${ }^{19}$ Finally, critics disagree about whether mere passive inhalation of marijuana smoke would test positive. ${ }^{20}$

Despite the scientific disputes surrounding drug testing, and the legal problems raised by such disagreements, ${ }^{21}$ this comment will assume that urinalysis accurately detects whether an individual has used drugs in the past. This assumption serves three purposes. First, it prevents this comment from becoming a survey of drug testing technology. Second, it acknowledges the strong probability that technological advances will ultimately correct the shortcomings of existing tests. Finally, it allows this comment to

17 Even the "beyond a reasonable doubt" standard requires some form of probability calculus. Michael Saks \& Robert Kidel, Human Information Processing and Adjudication: Trial by Heuristics, 15 Law \& Soc.Rev. 123 (1980). But see Laurence H. Tribe, Probability Calculus, 84 Harv.L.Rev. 1329 (1971) (the use of mathematical devices to rationalize adjudication may distort values which society pursues when conducting legal trials).

${ }^{18}$ Dogoloff, Urine Testing at 22 (cited in note 11); Urinalysis, for example, detects not the intoxicating element of marijuana, THC, but its byproduct, the THC metabolite, which remains in the body for extended periods of time. Comment, 20 Wake Forest L.Rev. at 397 (cited in note 11). Traces of other drugs, like marijuana, also remain in the body for extended lengths of time. For a survey of the times these drugs stay in the body see Chicago Tribune, Tomorrow Section 6, at 1 (May 25, 1986).

${ }^{19}$ National Institute on Drug Abuse, Q. \& A., Detection of Drug Use by Urinalysis 13 (1986); Arthur J. McBay, Cannabinoid Testing: Forensic and Analytical Aspects, 23 Lab.Mgmt. 36, 63 (1985). Some studies have attempted to measure an individual's performance while under the influence of drugs. For these results, see Jerome A. Yesavage, Von Otto Leirer, et al., Effects of Marijuana Intoxication on Aircraft Pilot Performance: A Preliminary Report, 142 Am.J.Psych. 1325 (1985); G. Barnett, V. Licko \& T. Thompson, Behavioral Pharmacokinetics of Marijuana, 85 Psychopharmacology 51 (1985).

${ }^{20}$ Dogoloff, Urine Testing at 23 (cited in note 11).

${ }^{21}$ It is debatable whether, and under what circumstances, a court may admit test results into evidence in criminal prosecutions. See Comment, 20 Wake Forest L.Rev. at 408 (cited in note 11) (arguing that courts should only admit MS results as evidence of drug use). Moreover, if authorities use test results as a basis for disciplinary proceedings, courts have prescribed elaborate safeguards to ensure that the authorities do not violate subjects' due process rights. Banks v. F.A.A., 687 F.2d 92 (5th Cir. 1982); see also Wykoff v. Resig, 613 F.Supp. 1504 (N.D.Ind. 1985)(creating elaborate safeguards to ensure that authorities preserve a subject's due process rights); Jones v. McKenzie, 628 F.Supp. 1500, 1506 (D.D.C. 1986)(dismissing bus driver on basis of single unconfirmed EMIT test is arbitrary and capricious). Courts also have had to grapple with existing scientific uncertainties as a factor in determining the "reasonableness" of the search under the fourth amendment. See, e.g., Storms v. Coughlin, 600 F.Supp. 1214, 1221 (S.D.N.Y. 1984). 
focus on a constitutional testing proposal rather than the potential legal problems raised by the accuracy of drug tests.

\section{A Drug Testing Proposal}

Drug testing presents a conflict between individual and government interests. The following model random testing program ("Drug Testing Proposal") strikes the necessary balance between these interests. As demonstrated in later parts of this comment, this proposal addresses fourth amendment and due process concerns while implementing a random testing program that furthers government interests. ${ }^{22}$

\section{Drug Testing Proposal}

(1) "Federal employees" are employees to whom the federal government pays a wage or salary. "Federal employment applicants" are those persons applying for positions as federal employees.

(2) A federal agency, the Federal Drug Testing Agency "(FDTA)", shall promulgate procedures to test federal employees and federal employment applicants. The agency shall select for testing categories of employees and applicants based on evaluation of the government's interest in preventing drug use by such persons. At a minimum, a permissible procedure will:

(a) randomly test all federal employment applicants and all federal employees applying to or employed in a selected agency, sector, unit, or department of the government. The FDTA shall test all such employees and applicants similarly situated;

(b) (i) in the case of federal employees, the procedure will be preceded by advance warning to the employee that the test will occur within six months. Such warning will not release the exact date of testing.

(ii) in the case of federal employment applicants: such persons will have seven days advance notice before a test is administered, accruing from the time the applicant applies for government

${ }^{22}$ For an account of pending and suggested state legislation on random testing, see Note, Employee Drug Testing Legislation: Redrawing the Battlelines in the War on Drugs, 39 Stan.L.Rev. 1453 (1987). 


\section{employment.}

(3) Employees of the FDTA will directly conduct and supervise urinalysis testing. While conducting such tests, FDTA employees:

(a) shall have no discretion regarding whom they will test.

(b) shall not engage in direct observation of the federal employee or federal employment applicant while such person provides a urine sample. Other procedures to prevent substitution of samples may be employed in accordance with the "no direct observation" rule. ${ }^{23}$

(4) A federal employee or federal employment applicant testing positive for drug use, as determined by an Enzyme Immunoassay (EMIT) test, shall have the right to take a Gas Chromatography (GC) test within two days of a positive EMIT test result. A federal employee or federal employment applicant who contests the EMIT finding and decides to undergo a GC test must pay for the GC test if the GC test results confirm the positive finding of the EMIT test. If the test results of the GC test indicate that the EMIT test findings were in error, the government shall pay the cost for the GC test. The GC test findings are binding on all parties. ${ }^{24}$

(5) Consequences of Testing Positive

(a) Federal employment applicants testing positive for drug use shall be prohibited from becoming a federal employee until they pass a urinalysis test.

(b) Federal employees testing positive for drug use are allowed two opportunities for rehabilitation after positive drug tests. If the employee fails to make use of these opportunities, the government may termi-

${ }^{23}$ Concerns that the lack of surveillance may result in the substitution of samples can be met by using various procedures, including: (1) checking the temperature of the sample to assure it is not a substitute, (2) attaining a second sample shortly after the first because it is unlikely a party will carry two or more substitute samples, and (3) conducting tests without a precise warning of the day the test will be conducted.

24 This provision addresses the accuracy concerns raised in part I of this comment. Because an EMIT test is only 95 percent accurate, critics of urinalysis point to the need for a test which will reduce this 5 percent probability of error. The GC test is virtually one hundred percent accurate. By shifting the cost burden to the employee or applicant, this provision also assures that drug users who test positive under the EMIT test will be deterred from taking their chances on the second test incorrectly exculpating them. The brevity of the two-day period between the EMIT results and the GC test lessens the likelihood that the GC test will show a negative result solely due to the dissipation of drugs in the body over time. 
nate the employee pursuant to the procedures outlined below. The government shall bear the expense for the first rehabilitation program. The employee shall bear the cost of the second rehabilitation program. After two such rehabilitation programs, the government may terminate the employee if he or she again tests positive for drug use. Before such termi- nation, the government must provide the employee with oral or written notice of the charges against him or her and give the employee: (1) an opportunity to show any error that may exist; (2) the names and nature of the testimony of witnesses against the employee; (3) a meaningful opportunity to be heard in his own defense; and (4) a hearing before an impartial administrator prior to termination.

(6) Urine samples obtained from federal employees or federal employment applicants shall be used for the sole purpose of drug testing. The results of such tests will remain confidential. Only the federal government will use the drug test results and the government will use the results solely to make federal employment decisions. Drug test results will not be used for criminal prosecution or released to any other government agency. The government shall destroy a government employee's drug test results within three years after the employee provided the urine sample.

\section{Fourth Amendment Concerns Implicated by Government EMPLOYEe URINALYSIS}

The purpose of the fourth amendment ${ }^{25}$ is straightforward: to prevent the government ${ }^{26}$ from engaging in unreasonable searches

${ }_{28}$ The fourth amendment reads in pertinent part:

The right of the people to be secure in their persons .. against unreasonable searches and seizures shall not be violated.

U.S. Const. amend. IV.

${ }^{28}$ See, e.g., Curdeau v. McDowell, 256 U.S. 465, 475 (1921) (fourth amendment's "origin and history clearly show that it was intended as a restraint upon activities of sovereign authority"). In the urinalysis context, private employers can screen employees for drug use without implicating the fourth amendment. See, e.g., Monroe v. Consolidated Freightways, 654 F.Supp. 661, 663 (E.D.Mo. 1987). For sources concerning a private employer's right to test its employees for drugs see Katherine Bishop, Drug Testing Comes to Work, Cal.Lawyer 28 (April 1986); Geidt, 11 Emp.Rel.L.J. 181 (cited in note 6); Rothstein, 11 Emp.Rel.L.J. 422 (cited in note 10). 
and seizures of individuals. ${ }^{27}$ However, an individual's right to be free from government intrusions is not absolute. The context in which fourth amendment rights arise shapes the content and incidents of such rights; ${ }^{28}$ acts permissible in one context violate the fourth amendment in another.

The "fluctuant" nature of an individual's fourth amendment rights is of crucial importance. This aspect of fourth amendment doctrine suggests that all drug testing of government employees or employment applicants is not a per se violation of the fourth amendment. The amendment does not foreclose the possibility that a limited governmental intrusion may be permissible in a given context.

\section{A. Urinalysis: Neither a Seizure nor a Search}

The threshold question in fourth amendment analysis is whether the government activity of concern is a "seizure" or "search." 29 This subsection deals primarily with the argument that urinalysis of government employees constitutes a search, largely because the argument that urinalysis constitutes a seizure is not widely accepted. In the context of government employee urinalysis, a seizure may occur "at two levels-the seizure of the person necessary to bring him into contact with the government . . and the

Commentators have suggested extending fourth amendment doctrine to include large private corporations. See, e.g., Friedmann, Corporate Power, Government by Private Groups, and the Law, 57 Colum.L.Rev. 155 (1957). As Professor Friedmann has noted, "Corporate organizations of business and labor have long ceased to be a private phenomenon." Id. at 176. "They have a direct and decisive impact on the social, economic, and political life of the nation." Id. The Court so far has been reluctant to adopt the position of such commentators, noting that "[c]areful adherence to the 'state action' requirement preserves an area of individual freedom by limiting the reach of federal judicial power." Lugar v. Edmondson Oil Co., 457 U.S. 922, 936-37 (1982).

${ }^{27}$ The Supreme Court has held that the fourth amendment specifically protects individuals and not places from unreasonable searches. Terry v. Ohio, 392 U.S. 1, 19 (1968); Katz v. United States, 389 U.S. 347, 351 (1967).

${ }^{28}$ Terry, 392 U.S. at 9 . See also United States v. Thomas, 729 F.2d 120, 123-24 (2d Cir. 1984); Callaway, 518 F.2d at 476.

29 This threshold inquiry is extremely important. As Professor Amsterdam has noted: The question of what constitutes a covered "search" or "seizure". . . should be viewed with an appreciation that to exclude any particular pclice activity from coverage is essentially to exclude it from judicial control and from the command of reasonableness, whereas to include it is to do no more than say that it must be conducted in a reasonable manner.

Anthony G. Amsterdam, Perspectives on the Fourth Amendment, 58 Minn.L.Rev. 349, 393 (1974). See also Horton v. Goose Creek Independent School District, 690 F.2d 470, 476 (5th Cir. 1982). 
subsequent search for and seizure of the evidence."30 Case law supports the contention that no "seizure" of a person occurs when a public employer directs an employee to report to a facility during working hours for the collection of a urine sample. ${ }^{31}$ The government does not impede an employee's freedom of movement when it directs the employee to report to a urine collection site any more than the government impedes freedom of movement by directing the employee to go to his usual work site. An employee already has accepted a restriction on his freedom of movement imposed by his obligation to his employer..$^{32}$ Arguably, these same considerations apply to employment applicants. When applying for government employment, an applicant impliedly accepts an employer's right to restrain the applicant's movement temporarily. If he reports to the facility for testing, the applicant consents to contact with the government.

Similarly, the act of collecting urine is, in most circumstances, not a "seizure." Urine is a body waste, typically abandoned without concern. It is not the property of an individual to which one attaches a possessory interest. ${ }^{33}$ This argument is not meant to suggest that the taking of a urine sample is per se not a seizure. Such a per se line would be inappropriate: even the abandonment of urine might constitute a seizure in some circumstances. As the Ninth Circuit has said, "the proper test for abandonment is not whether all formal property rights have been relinquished, but whether the complaining party retains a reasonable expectation of privacy in the articles alleged to be abandoned."34 Nonetheless, as

${ }^{30}$ United States v. Dionisio, 410 U.S. 1,8 (1973).

s1 See Biehunik v. Felicetta, 441 F.2d 228, 231 (2d Cir. 1971) (compulsory lineup of police department employees permissible because it "was to be conducted at a time and place that were well within the usual demands of a policeman's job"). See also Turner v. Fraternal Order of Police, 500 A.2d 1005, 1011 (D.C. App. 1985)(Nebeker concurring)(employment context in which a urine sample is given "eliminates any issue of seizure of the officer's [government employee's] person").

${ }^{32}$ See I.N.S. v. Delgado, 466 U.S. 210, 218 (1984)("ordinarily when people are at work their freedom to move about has been meaningfully restricted . . . by the workers' voluntary obligations to their employers").

${ }^{33}$ Some courts have suggested as much: see, e.g., Venner v. State, 367 A.2d 949, 956 (Ct.App.Md. 1977) (no property right in excretion because it is the human experience to abandon it immediately); Turner, 500 A.2d at 1011 (Nebeker concurring)(one "logically" cannot retain any possessory right in one's urine); Raab, 816 F.2d at 176 (same). But see Bostic v. McClendon, 650 F.Supp. 245, 249 (N.D.Ga. 1986)(holding government taking of a urine specimen as a "seizure" while erroneously citing cases which have held it is a "search").

${ }^{34}$ United States v. Wilson, 472 F.2d 901, 902 (9th Cir. 1972)(citations omitted). See also Alinovi v, Worcester School Committee, 777 F.2d 776, 781 (1st Cir. 1985). 
the discussion of "searches" below will show, the reasonable expectation of privacy concern is minimal in the context of this comment's Drug Testing Proposal. One properly can conclude that urine samples taken pursuant to this proposal are not seizures within the meaning of the fourth amendment.

The main focus of court decisions dealing with urinalysis has been on whether such a procedure constitutes a search of the employee's person, not on whether urinalysis constitutes a seizure. Urinalysis is a "search" implicating the fourth amendment only if it infringes upon an individual's expectation of privacy. Traditionally, the courts have applied a two-part test when deciding upon a claim that the government has infringed an individual's expectation of privacy. First, the individual must exhibit a "subjective expectation of privacy." Second, the expectation must be "one that society considers reasonable." ${ }^{36}$ A search of objects that a person knowingly exposes to the public, ${ }^{36}$ or a search of objects pursuant to an individual's consent, ${ }^{37}$ does not implicate the fourth amendment. Although courts are virtually unanimous in holding that urine tests invade an employee's expectation of privacy and are therefore fourth amendment searches, ${ }^{38}$ courts have taken various approaches when addressing this question. Some liken required urinalysis to the taking of an involuntary blood sample. ${ }^{30}$ Others

${ }^{35}$ Katz v. United States, 389 U.S. 347, 361 (1967)(Harlan concurring). The Supreme Court has ruled that the subjective test is irrelevant in certain circumstances, and that the objective test is controlling in those circumstances. See, e.g., Hudson v. Palmer, 468 U.S. 517, 525 n.7 (1984).

36 Utilizing the "knowingly exposes to the public" standard, courts have reasoned that the taking of voice and handwriting samples are not fourth amendment "searches". Dionosio, 410 U.S. at 14 (1973)(voice); United States v. Mara, 410 U.S. 19, 21 (1973) (handwriting).

${ }^{37}$ Schneckloth v. Bustamonte, 412 U.S. 218 (1973).

ss See, e.g., Division 241 Amalgamated Transit Union v. Suscy, 538 F.2d 1264, 1268 (7th Cir. 1976); Shoemaker v. Handel ("Shoemaker II"), 619 F.Supp. 1089, 1098 (D.N.J. 1985); Tucker v. Dickey, 613 F.Supp. 1124, 1129-30 (W.D.Wis 1985); Storms, 600 F.Supp. at 121820; Macias v. State, 649 S.W.2d 150, 152 (Tex.App. 1983); Capua v. City of Plainfield, 643 F.Supp 1507, 1513 (D.N.J. 1986); Caruso v. Ward, 506 N.Y.S. 2d 789, 797 (N.Y. Sup. Ct. 1986); Turner, 500 A.2d at 1005; Lovvorn, 647 F. Supp. at 879; Raab, 816 F.2d at 175; Smith v. City of East Point, No. 73757, slip op. at 5 (Ct.App.Ga. June 24, 1987); Mullholland v. Dept. of Army, 660 F.Supp. 1565, 1568 (E.D.Va. 1987); Amalgamated Transit Union, Local 1277 v. Sunline Transit Authority, 663 F.Supp. 1560, 1566 (C.D.Cal. 1987); Smith v. White, No. Civ-1-87-187, slip op. at 5 (E.D.Tenn. Aug. 11, 1987); Rushton v. Nebraska Public Power District, 653 F.Supp. 1510, 1523 (D.Neb. 1987).

One court has hinted that urinalysis may not be a search. See, e.g., National Treasury Employees Union v. Von Raab, 808 F.2d 1057, 1060, 1062 (5th Cir. 1987) (Higginbotham concurring) (questioning whether requiring urine specimens from applicants for sensitive positions in United States Customs Service "is a search or seizure at all").

39 See, e.g., McDonnell v. Hunter, 809 F.2d 1302, 1307 (8th Cir, 1987); Allen v. City of 
rely on a "personal secrets rationale."40 And still others have blindly adhered to what they consider binding precedent. ${ }^{41}$ The argument shared by all of these courts is that "[o]ne does not reasonably expect to discharge urine under circumstances making it available to others to collect and analyze in order to discover the physiological secrets it holds."42 A further examination of the privacy concern will demonstrate, however, that the fourth amendment does not protect an individual's subjective expectation of privacy in certain contexts. Application of this comment's drug testing proposal is one such example.

1. Subjective Expectation of Privacy. The first prong of the Katz test directs attention to an individual's subjective expectation of privacy. Although the Supreme Court has cautioned that the subjective expectation of privacy is in some circumstances "an inadequate index" of fourth amendment protection, ${ }^{43}$ the subjective component of the Katz test retains a very general utility. Even where the courts rely on the existence of an objective expectation of privacy-that is, an expectation that society would consider reasonable-an individual's subjective expectation of privacy may be relevant: if the subjective expectation is great, courts are more likely to find that the government has violated the fourth amendment. ${ }^{44}$

When evaluating an individual's subjective expectation of privacy in the urinalysis context, courts must consider two factors: the testing methods used and the individual's status as a government employee..$^{45}$ Many have recognized the privacy accorded to urination; a number of courts, for example, have reasoned that drug testing is too intrusive a search ${ }^{46}$ because government surveil-

Marietta, 601 F. Supp. 482, 488 (N.D.Ga. 1985); Lovvorn, 647 F.Supp. at 879; Storms, 600 F.Supp. at 1218 .

40 Raab, 816 F.2d at 170 (5th Cir. 1987); McDonnell, 809 F.2d at 1307; Capua, 643 F.Supp. at 1513; Bostic, 650 F.Supp. at 249; Caruso, 506 N.Y.S.2d at 789.

${ }^{41}$ See, e.g., National Federation of Gov't. Employees v. Weinberger, 818 F.2d 935 (D.C.Cir. 1987); Patchogue-Medford Congress of Teachers v. Board of Education, 505 N.Y.S.2d 888, 890 (N.Y.App.Div. 1986).

42 McDonnell, 612 F.Supp. at 1127.

${ }^{43}$ Smith v. Maryland, 442 U.S. 735, 740 n.5 (1979).

14 Smith v. City of East Point, No. 73757 slip op. at 2.

is Shoemaker v. Handel ("Shoemaker I"), 608 F.Supp. 1151, 1158 (D.N.J. 1985) (a court must consider an individual's expectations of privacy "under the circumstances").

${ }^{48}$ Courts, however, have considered this factor when deciding if urinalysis in the context of a given case constituted an unreasonable search rather than when deciding whether urinalysis constituted a search at all. See, e.g., McDonnell, 612 F.Supp. at 1127; Capua, 643 F.Supp. at 1513; Storms, 600 F.Supp. at 288-89; Allen, 601 F.Supp. at 488. 
lance of urination is "very embarrassing and humiliating." proposition that urinating while under observation is embarrassing suggests that a procedure which bars such observation substantially lessens the privacy concern. Section 3(b) of the Drug Testing Proposal therefore provides that the FDTA officials administering the test shall not directly observe an employee during urination. Under such conditions, providing a urine sample is akin to the normal performance of a routine bodily function and does not violate an individual's actual expectation of privacy. ${ }^{48}$

Some courts have ruled that an individual not only has an expectation of privacy in the process of urination but also in the information contained in the urine. ${ }^{49}$ These courts reason that examination of the urine sample will reveal other personal secrets that the government has no right to know. Under this view, any examination of urine will be a search.

The Drug Testing Proposal addresses this argument. Section 6 of the proposal allows testing only for illicit drug use and such results are strictly confidential. The Supreme Court has recently said, in the law enforcement context, that testing which reveals whether an individual has used drugs "and no other arguably "private' fact, compromises no legitimate privacy interest."

In addition to testing procedures, status as a government employee or employment applicant affects an individual's subjective expectation of privacy. In both the public and private sectors, an employee or applicant has a lesser expectation of privacy about information relevant to the employee's job or the applicant's prospective job because an employer, consistent with the very nature of employment, has the prerogative to conduct reasonable inquiries into an employee's or applicant's fitness for duty. ${ }^{\text {s1 }}$ In the federal

\footnotetext{
${ }^{17}$ Capua, 643 F.Supp. at 1514.

${ }^{48}$ For a discussion of unintrusive procedures to detect substitution of urine samples, see note 23.

19 See, e.g., Raab, 816 F.2d at 175-176.

${ }^{\text {so }}$ United States v. Jacobsen, 466 U.S. 109, 123 (1984) (footnotes omitted).

${ }^{31}$ A powerful argument might be made that an employer's need to oversee an employee's fitness for duties does not extend to situations where an employee's off-duty behavior does not affect his job performance. This argument, however, ignores two concerns. First, a federal employee is an outward symbol of the federal government. In a very real sense the federal government has an interest in assuring that he presents a proper image of his organization. Of course, this argument is weak with regard to employees not easily recognized as affiliated with the government. Second and more important, it is more costly-potentially impossible - to monitor a slight decrease in an employee's efficiency (for example, 10 percent) by means of observing his performance. Because slight decreases in efficiency over the government as a whole can represent a substantial loss, testing designed to prevent drug use offers an optimal solution. See also cases cited in note 56.
} 
government, for example, employees and applicants routinely submit to physical examinations which often include urine testing and full field background investigations. ${ }^{62}$ Courts in the urinalysis context, moreover, have recognized that there is "no constitutional difficulty with . . . regularly conducted physicals or the requested physicals, or a pre-employment physical, even if they involve urinalysis for drugs." nations also supports the requirement of drug tests through urinalysis: employees and applicants accept employer perlustration as an unstated condition of employment. As a result, their actual expectation of privacy is lower.

Courts have also recognized that a government employee's subjective expectation of privacy is reduced precisely because the employee works for the government rather than for a private employer. ${ }^{.4}$ For example, courts have repeatedly noted that-based upon the nature of their employment-correction and law enforcement officers have a reduced expectation of privacy. ${ }^{55}$ In addition, one court has reasoned that FBI agents' expectations of privacy are diminished because their employer advised them in advance of the FBI's strong interest in assuring the integrity of its agents. ${ }^{56}$ When applied to this comment's Drug Testing Proposal, these cases suggests that the government employee's subjective expectation of privacy is lower than it might otherwise be if the employee worked for a private employer.

The employment context argument is problematic, however.

$\$ 2$ The federal government requires employees in, or applicants for, positions with physical or medical standards to submit to physical examination prior to appointment or selection, 5 C.F.R. 339.301(a)(1) (1987), on a regularly recurring periodic basis, id. at $339.301(a)(2)$, or whenever a question arises about an employee's capacity to meet the physical or medical qualifications of the position. Id. at 339.30 (a)(3). For courts upholding routine physicals as constitutional, see Brachter v. United States, 149 F.2d 742, 745 (4th Cir. 1945); McDonnell, 612 F.Supp. at 1130 n.6; Curry v. New York Transit Authority, 56 N.Y.S.2d 798, 437 N.E.2d 1158 (N.Y. Sup. Ct. 1982). The government also conducts extensive full-field investigations into applicant's backgrounds for sensitive positions in the federal service. See Federal Personnel Manual, Chapter 733.

${ }^{53}$ Lovvorn, 647 F.Supp. at 881 n.7; Fraternal Order of Police, Newark Lodge No. 12 v. City of Newark, 524 A.2d 430, 434 n.6 (Sup.Ct.N.J. 1987). But see Feliciano, 661 F.Supp. at 583 (implying physical exams and urinalysis are not similar).

st Pervasive government regulation of private industry also reduces an individual's expectation of privacy. See Shoemaker v. Handel (Shoemaker III), 795 F.2d 1136, 1142 (3d Cir. 1986); Patchogue-Medford, 505 N.Y.S.2d at, 904.

ss McDonnell, 809 F.2d at 1306; Sec. \& Law Enforcement Emp., Dist. Council 82 v. Carey, 737 F.2d 187, 202 (2d Cir. 1984); Biehunik v. Felicetta, 441 F.2d 228, 231 (2d Cir. 1971).

so Mack v. United States, FBI, 653 F.Supp. 70, 75 (S.D.N.Y. 1986), aff'd, Mack v. United States, 814 F.2d 120 (2d Cir. 1987). 
Opponents of testing argue, for example, that a mere warning may not substitute for fourth amendment protections. An extreme form of the warning rationale would mean that the government could search individuals at will if warnings were given which reduced an individual's subjective expectation of privacy. While ignoring the reasonable expectation of privacy prong of the test, the critics' argument does point to a difficulty with the subjective expectations prong: its circularity. A government activity is only a "search" if it implicates an individual's actual expectation of privacy which, in turn, varies depending on the government activities that precede or accompany the search. Commentators and courts alike have recognized that this test alone is insufficient to protect fourth amendment interests. ${ }^{57}$ Thus, in determining whether government action constitutes a search, courts have focused on an individual's reasonable expectation of privacy.

2. Reasonable Expectation of Privacy. The second prong of the "search" analysis says that a "search" occurs only when government activity infringes on an individual's expectation of privacy that "society is prepared to recognize as 'reasonable." "ss Standards of "reasonableness" vary for different individuals and circumstances ${ }^{59}$ because the fourth amendment does not recognize privacy interests in the abstract, but only in the concrete circumstances of each case. ${ }^{60}$ In the urinalysis context, courts have recognized this principle and have therefore concentrated upon the facts involved in the case before the court. ${ }^{61}$

In the employment context, courts take into account two factors when defining the scope of the privacy interests that society

${ }^{57}$ See Amsterdam, 58 Minn.L.Rev. at 384 (cited in note 29), commenting that: an actual expectation of privacy obviously has no place in a statement of what Katz held or in a theory of what the fourth amendment protects. It can neither add to, nor can its presence detract from, an individual's claim to fourth amendment protection. If it could, the government could diminish each person's subjective expectation of privacy merely by announcing half-hourly on television that ... we are forthwith being placed under comprehensive electronic surveillance.

${ }^{88} \mathrm{Katz}, 389$ U.S. at 361.

${ }^{39}$ For example, courts do not regard a politician to have as great an expectation of privacy as an individual citizen. See New York Times Co. v. Sullivan, 376 U.S. 254 (1964)(recognizing a lower degree of privacy for political figures in a first amendment context). See also O'Connor v. Ortega, 107 S.Ct. 1492, 1498 (1987)(public employee's reasonable expectation of privacy "must be assessed in the context of the employment relationship").

${ }^{\circ 0}$ See Ortega, 107 S.Ct. at 1498 ("question of whether an employee has reasonable expectation of privacy must be addressed on a case by case basis"); Callaway, 518 F.2d at 476 ("What is reasonable in one context may not be reasonable in another").

${ }^{61}$ See Callaway, 518 F.2d at 476; Fraternal Order of Police, Newark Lodge No. 12, 524 A.2d at 435; Feliciano, 661 F.Supp. at 588; Raab, 816 F.2d at 176. 
recognizes as "reasonable:" (1) the deference usually granted by courts with regard to conditions of employment, and (2) the intrinsic nature of the occupation. Traditionally, courts have afforded employers broad latitude in defining conditions or regulations of employment. ${ }^{62}$ Courts also have recognized that this latitude may reduce an individual's reasonable expectation of privacy. ${ }^{63}$ In particular, courts have allowed government employers great freedom in conducting reasonable inquiries into an employee's fitness for duties. ${ }^{64}$ They recognize, moreover, that the fourth amendment does not prevent the government from exercising its power as an "employer to supervise and investigate the performance" of its employees. ${ }^{65}$ Because courts widely recognize that the government can impose conditions on employment, the legitimate expectation of privacy accorded federal employees requested to undergo fitnessrelated urinalysis is limited. Urinalysis is a condition of employment similar to physical exams which, as mentioned earlier, have not been classified as searches.

Critics raise the argument that urinalysis is distinct from other conditions of employment because it seeks to impose restrictions on what an employee does in his off-duty time. This argument, however, is not convincing. Urinalysis tests reflect the employer's prerogative to discover worker impairments, not a desire to monitor an employee's off-duty conduct. If an employee's activities affect his work performance, an employer has every reason to deter such activities. Urinalysis, like a physical exam, detects shortcomings in an employee that a supervisor cannot easily discover through observation of work performance. ${ }^{66}$ An employer must be able to detect even slight defects in performance since even small impairments can prove extraordinarily costly. Thus, as

${ }^{62}$ See NLRB v. Jones \& Laughlin Steel Corp., 301 U.S. 1, 45-46 (1937) (National Labor Relations Act respects employers' right to hire and discharge workers). See also Carey, 737 F.2d at 203; Caruso, 506 N.Y.S.2d at 791 (employer may place reasonable conditions on job including scrutiny for drug use).

${ }^{63}$ See United States v. Donato, 269 F.Supp. 921, 923 (E.D.Pa. 1973)(employee's privacy interest in his locker held subject to employer's rules and regulations); United States v. Bunkers, 521 F.2d 1217, 1220 (9th Cir. 1975)(no reasonable expectation of privacy in view of pervasive regulation of the workplace); Duplantier v. United States, 606 F.2d 654, 670 (5th Cir. 1979).

${ }^{64}$ See cases cited in note 52; see also Raab, 816 F.2d at 178.

6s United States v. Collins, 349 F.2d 863, 868 (2d Cir. 1965). United States v. Nasser, 476 F.2d 1111, 1123 (7th Cir. 1973)(electronic surveillance of IRS employee to verify whether he was properly performing IRS work in his IRS office not unreasonable).

${ }^{86}$ See Mullholland, 660 F.Supp. at 1569 (direct observation provides little basis to assess an individual's possible use of drugs; tests are more conclusive). But see Feliciano, 661 F.Supp. at 586 (observation alone should indicate drug use). 
is the case with physical exams, courts should rule that urinalysis tests are not searches.

Conditions on employment reduce an employee's expectation of privacy in a second way as well: society is less likely to recognize the expectation as objectively reasonable if the employer has warned the employee through conditions on employment that a test is likely to occur. ${ }^{67}$ In Shoemaker $v$. Handel, ${ }^{68}$ for example, a third circuit court found that racing jockeys had no legitimate expectation of privacy vis-a-vis urinalysis because they knew such tests were a possibility when they became involved with the horseracing industry. Moreover, where objective rather than subjective expectations of privacy are at issue, there is no danger that recognition of the manner in which warnings diminish expectations of privacy will undermine fourth amendment guarantees entirely. Where purely subjective expectations are at issue, a warning may undercut completely an individual's expectation of privacy. By contrast, where objective expectations are at issue, a warning will always be only one factor in determining if an individual's expectation is reasonable. ${ }^{69}$

Besides the deference traditionally granted to employers with regard to employee regulations, an additional factor governs reasonable expectations of privacy in the present context: courts in the urinalysis context have found that the nature of the employee's occupation may affect the employee's reasonable expectation of privacy. As one federal district court reasoned, regardless of occupation, individuals "have an expectation of privacy upon taking a position with the government that is diminished in comparison with that reasonably held by members of the public at large."7o More specifically, courts have recognized that public employees such as military personnel, ${ }^{71}$ policemen, ${ }^{72}$ firefighters, ${ }^{73}$ corrections

67 See United States v. McIntyre, 582 F.2d 1221, 1224 (9th Cir. 1978) ("An established regulatory scheme or specific office practice may ... diminish an employee's reasonable expectation of privacy."); United States v. Davis, 482 F.2d 893 (9th Cir. 1973). Of course, the search warned of must be reasonable.

${ }^{68} 795$ F.2d 1136, 1142 (3d Cir. 1986) ("Shoemaker III").

'B See §2(b) of the Drug Testing Proposal.

70 American Federation of Government Employees, 651 F.Supp. at 733 (considering constitutionality of urinalysis testing program). See also Lovvorn, 647 F.Supp. at 880 ("employees, as opposed to the general citizenry, have a somewhat diminished expectation of privacy"); Fraternal Order of Police, Newark Lodge No. 12, 524 A.2d at 436; Feliciano, 661 F.Supp. at 588 (court "ascribes to the universally recognized proposition that by accepting government employment, public employees' legitimate expectations of privacy are somewhat less than that of their private sector counterparts").

${ }^{71}$ Callaway, 518 F.2d at 477.

72 Turner, 500 A.2d at 1008; Biehunik, 441 F.2d at 231. 
officers, ${ }^{74}$ and bus drivers ${ }^{75}$ have a different and reduced expectation of privacy as a result of their occupations.

If one interprets this case law restrictively, only those government employees entrusted with public safety have a significantly reduced expectation of privacy. Under this line of reasoning, a postal clerk, for example, might not have a reduced reasonable expectation of privacy while police officers and bus drivers would. This reasoning, however, underestimates the distinction between public employees and private employees. Public employees do not pose a greater threat to public safety than private employees. Many workers in the private sector, construction workers for example, can harm the public if negligent. Rather, it is more reasonable for the government to regulate public employees because such persons are servants of the public and hence answerable to public officials. The postal worker is no less of a public servant than the police officer. In both cases, precisely because the employees are public servants, the government has both a general interest in projecting a positive public image and a specific interest in assuring efficient use of public resources. Coupling the broad latitude of employers to establish conditions of employment with the employee's reduced expectation of privacy as a government employee, a court should not recognize a reasonable expectation of privacy where the government uses urinalysis to determine an employee's fitness for duties. As long as the government limits itself to testing only for illicit drug use, no "search" occurs when a government employee undergoes a urine test as a reasonable condition of employment. ${ }^{76}$

3. Consent of Public Employees and Applicants. A theory of consent also may justify drug testing of government employees since consent negates an individual's reasonable expectation of privacy. ${ }^{77}$ To alleviate fourth amendment concerns, however, such consent must be voluntary and not coerced "by explicit, or implicit

${ }^{73}$ See, e.g., City of Palm Bay v. Bauman, 475 So.2d 1322, 1324 (Fl.App. 1985); Lovvorn, 647 F.Supp. at 880.

${ }^{74}$ McDonell, 612 F.Supp. at 1128; Carey, 737 F.2d at 202.

${ }^{76}$ Suscy, 538 F.2d at 1267; Jones, 628 F.Supp. at 1508.

${ }^{78}$ Only if the government seeks to investigate the personal concerns of its employees-actions distinct from employee performance-does a search occur. Such an investigation would not be a reasonable condition of employment. Examples of such searches include venereal disease testing, psychological profile tests not relevant to a party's occupation, and investigations into aspects of a party's ethnic background and political leanings which are not relevant to the occupation in question. A search also might occur if the government investigation goes beyond a basic full physical exam or psychological study. But a random drug testing program, unlike these examples, is not a search.

${ }^{77}$ United States v. Matlock, 415 U.S. 164, 170 (1974). 
means, by implied threat or covert force."78 Therefore, an important question in the context of urinalysis is whether government employees or applicants voluntarily consent to such tests as a condition of employment. ${ }^{79}$

Consent can take two forms: express or implied. Express consent occurs when an individual consents to the test orally or in writing. Implied consent occurs when an individual undergoes the test without objection, or otherwise acts in a way which reasonably indicates that he finds the test unobjectionable. ${ }^{80}$ When courts have considered the issue of government employee consent in the urinalysis context, both forms of consent have been present. ${ }^{81}$

Nonetheless, courts have found that consent does not validate a "search." Some courts have explained this conclusion by reasoning that "consent to future unreasonable searches is not a reasonable condition of employment," $" 82$ and thus not legitimate consent. An analysis of the "reasonableness" of such searches appears later in this comment. More important for present purposes, at least one court has held that a government employee does not consent to required urinalysis where the penalty for refusal is termination, arguing that consent in circumstances where the employee "legitimately fear[s] termination" is coercive. ${ }^{83}$

${ }^{38}$ Schneckloth, 412 U.S. at 228 . Voluntariness is a question of fact the court must determine "from all the circumstances." Id. at 248-49. Voluntary consent can exist even though a party does not know he has the right to refuse to give his consent. Id. at 249. However, a person's knowledge of this right to refuse may be taken into account when considering the voluntariness of consent. Id.

79 The concepts of consent and waiver are distinct. If one consents to a government investigation, it is not a search. If one waives constitutional rights, then a search occurs; one merely does not contest such activity. In the urinalysis context, courts have held that the government cannot condition employment on waiver of an employee's fourth amendment rights. Caruso, 506 N.Y.S.2d at 793; American Federation of Government Employees, 651 F.Supp. at 736. See also Ortega, 107 S.Ct. at 1498-99 (search must be "reasonable condition of employment").

${ }^{80}$ See, e.g., United States v. Sihler, 562 F.2d 349 (5th Cir. 1977) (finding consent where large sign passed each day by prison employees warned that all persons entering prison were subject to search); United States v. Griffin, 530 F.2d 739, 742 (7th Cir. 1976)(one can consent through words, gestures or conduct).

${ }^{81}$ For cases considering express signed consent forms, see McDonell, 612 F.Supp. at 1131; Caruso, 506 N.Y.S.2d at 791; American Federation of Government Employees, 651 F.Supp. at 736. For cases considering implied consent, see Shoemaker III, 795 F.2d at 1142; Bostic, 650 F.Supp. at 249; Feliciano, 651 F.Supp. at 591.

${ }^{82}$ McDonell, 612 F.Supp. at 1131 (original emphasis); Caruso, 506 N.Y.S.2d at 792-93; American Federation of Government Employees, 651 F.Supp. at 736. For the general proposition that government employers cannot require employees to consent to unreasonable searches as a condition of employment, see Pickering v. Board of Education, 391 U.S. 563, 568 (1968); Frost Trucking Co. v. Railroad Commission, 271 U.S. 583, 593-94 (1926).

${ }^{83}$ American Federation of Government Employees, 651 F.Supp. at 736. 
Such an assertion, although intuitively attractive, is incorrect. Termination of employment is the most extreme result of an employee's refusal to undergo urinalysis. ${ }^{84}$ Likewise, denial of employment for an applicant is the most serious consequence of a refusal to consent. However, these outcomes do not "coerce" employees to consent even though the result of an employee's refusal to consent is the termination of a voluntary employment relationship or the loss of an employment opportunity. ${ }^{85}$

In analogous contexts, for example, courts have found voluntary consent where individuals faced either a possible loss of economic livelihood or a loss of freedom of movement for failure to consent to a "search." First, courts have upheld consent where an individual decides whether to board a plane and submit to a "search," or to forego boarding the plane and thus avoid the "search." torneys choose to enter courthouses. As one court has noted in this context: "[A]lthough an attorney's consent to a search is exacted as the price of entering the courthouse to discharge duties necessary to his profession, the search is nevertheless consensual in the same way as in the airport cases." 87 Third, courts have held that anyone entering a military installation voluntarily consents to government "searches," even if the search is a mandatory requirement for entry. ${ }^{88}$ Fourth, the Supreme Court has found voluntary consent where the government makes public aid contingent on visits to the recipients' homes. ${ }^{89}$ Finally, in regard to urine testing, courts have found voluntary consent where (1) an individual operates a motor vehicle on a public road, ${ }^{90}$ or (2) where an individual chooses to

84 Courts have not yet considered any program involving a more extreme result such as criminal prosecution. See, e.g., American Federation of Government Employees, 651 F.Supp. at 736; Caruso, 506 N.Y.S.2d at 798.

${ }^{85}$ For a related case, see Zap, 328 U.S. 624, 628 (1946), judgment vacated on unrelated issues, 330 U.S. 800 (1947)(court found voluntary consent although the only way to attain government business was to submit to a search).

${ }^{86}$ See United States v. Doran, 482 F.2d 929, 932 (9th Cir. 1973).

${ }^{87}$ McMorris v. Alioto, 567 F.2d 897, 901 (9th Cir. 1978).

${ }^{88}$ United States v. Ellis, 547 F.2d 863, 866 (5th Cir. 1977); United States v. Matthews, 431 F.Supp. 70, 73 (W.D.Okla. 1976).

88 Wyman v. James, 400 U.S. 309, 317 (1971). Although the Supreme Court has not overturned this decision, other courts have criticized its logic. See, e.g., Feliciano 661 F.Supp. at 593 (refusing to apply Wyman in urinalysis context and suggesting that the case should be limited to its facts).

so State v. Williams, 201 N.W.2d 241, 242-43 (Nev. 1972) (implied voluntary consent to a test for intoxication). See also State v. Locke, 418 A.2d 843, 849 (R.I. 1980). Admittedly, these cases involve some form of reasonable suspicion (for instance, where the police officer stopped the party because he suspected intoxication) and are thus not wholly analogous to 
remain in a pervasively regulated industry with knowledge that the proper authorities will test for drug use. ${ }^{91}$

Admittedly, there are differences between magnetometer searches, courthouse searches, and urinalysis. In the magnetometer and courthouse situations, the search is directed toward weapons that might endanger public safety. In the case of urine testing for government employees, the link between drug testing and public safety often is nonexistent.

Some Supreme Court precedent suggests, however, that the public safety distinction does not explain existing case law. Consent in the public aid situation did not depend upon this distinction since the government did not search the recipients' homes in order to protect public safety. The Court nevertheless allowed the government to condition the receipt of benefits upon the recipients' voluntary consent to a search. ${ }^{92}$

Moreover, the similarities between the magnetometer and courthouse searches and required urinalysis are more compelling than the differences between these tests. First, the temporal aspect of the government activities is an important element in consent cases. In each situation, the government seeks to prevent certain activity during a discrete time period-for example, while the party is at work or in a plane. To prevent such activity, however, the government must regulate a party's actions before he enters the plane or begins work. In both cases, the government regulates a party's behavior before a given event is allowed to take place. A party cannot engage in a given activity unless his prior behavior is acceptable.

Potential economic duress is a second important similarity between required urinalysis and the consent cases. All of these searches involve choices that will affect an individual's economic livelihood. In the airplane and courthouse cases, courts have found valid consent to searches even though the price of nonconsent was substantial. ${ }^{93}$ Airline travel, for example, is "all but a necessity"94 for many occupations today. Nevertheless, courts hold that an individual boarding an airplane voluntarily consents to a search. Likewise, entering a courthouse is virtually a necessity for liti-

random urine testing or airport searches.

91 Shoemaker III, 795 F.2d at 1142.

92 See Wyman, 400 F.2d 309.

${ }^{03}$ This is precisely the choice that jockeys faced in Shoemaker III, 795 F.2d at 1142, where the court upheld random urine testing while alluding to employee consent as a factor in its decision.

94 McMorris, 567 F.2d at 900-01. 
gators, but courts have found that such persons voluntarily consent to courthouse searches, despite the harshness that refusal entails.

When compared with magnetometer and courthouse searches, the Drug Testing Proposal places no greater economic burdens on the employee for failure to consent than is put on the attorney or traveller. An employee who chooses not to comply with required urinalysis may have to find a new job. But the government employee's situation is no different from that of a litigator who refuses to consent to a courthouse search and must as a result change her entire line of work.

Accordingly, the fear that urinalysis might rob individuals of the opportunity to make a meaningful consent decision is misplaced. An employee's consent is voluntary in this context. As a result, urinalysis is not a "search" within the fourth amendment. ${ }^{95}$

\section{B. Is Urinalysis Reasonable?}

Even if courts regard urinalysis as a search, the "underlying command of the Fourth Amendment is always that searches and seizures be reasonable." "Reasonableness" in the fourth amendment context "is not capable of precise definition or mechanical application." Rather, in each case a court must determine whether a search is "reasonable" by balancing the invasion of personal rights entailed by the search against the need for the search. ${ }^{97}$

1. Intrusiveness of Urinalysis. "Reasonableness" does not turn solely on whether the government could have used less intrusive means to search. ${ }^{88}$ Rather, in each situation, a court must determine the "reasonableness" of a search by assessing the intrusive-

${ }^{\circ 5}$ Voluntary consent may be complicated in cases where a non-probationary public employee has a property right in public employment. Nonetheless, most programs considered do not involve termination as a result of the employee refusing to consent. But see 1st drug offense to cost U.S. workers their jobs, Chicago Tribune, at 3, col. 3 (Dec. 18, 1986). Moreover, the Drug Testing Proposal calls instead for rehabilitation following the first two instances in which an individual tests positive. This procedure alleviates the fear that an individual may lose his job by consenting to testing. See Drug Testing Proposal $\S 5(\mathrm{~b})$.

${ }^{96}$ T.L.O., 105 S.Ct. 733, 741 (1985). Courts use the word "reasonable" in two different contexts. First, a threshold inquiry determines whether the conduct at issue implicates a "reasonable" expectation of privacy triggering fourth amendment review. Katz, 389 U.S. at 361 (Harlan concurring). Second, once such a privacy interest is recognized, courts ask whether the government's conduct is "reasonable" by "balancing the need to search against the invasion which the search entails." T.L.O., 105 S.Ct. at 741.

${ }^{97}$ Bell, 441 U.S. at 559. See also T.L.O., 105 S.Ct. at 741; Tennessee v. Garner, 469 U.S. 877 (1985). For an economic approach to balancing under the fourth amendment, see Richard A. Posner, Economic Analysis of the Law 640 (3d ed. 1986); Richard A. Posner, Rethinking the Fourth Amendment, 1981 S.Ct.Rev. 49.

${ }^{28}$ Cady v. Pombrowski, 413 U.S. 433, 447 (1973). 
ness of the means that the government actually employed. Bodily intrusions such as forcing open a suspect's mouth to recover narcotics represent "conduct that shocks the conscience" and so violates the fourth amendment.99 Urinalysis is more difficult to classify because it "requires a normal bodily function" and "is not an extreme bodily invasion" 100 of the same magnitude.

Courts have not reached agreement on the intrusiveness of urinalysis. Some courts liken urinalysis to the indignity suffered in a body cavity search;"101 some find urinalysis "essentially indistinguishable" from a blood test; ${ }^{102}$ some assert that "urine testing. . .presents an even greater intrusion on privacy than does blood testing;"103 still others imply that urinalysis is less intrusive than a blood test. ${ }^{104}$

Intuitively, courts which view urinalysis as less intrusive than a blood test present the strongest argument. Urinalysis is a minimally intrusive search; it does not involve an intrusion into the skin, ${ }^{105}$ but merely the collection of a naturally and frequently disposed of waste product. As one court has noted, "[ $t]$ he collection of a urine sample has little in common with a stomach pumping. . . (or even with the taking of a blood sample, which requires the infliction of an injury, albeit a small one). It is even less intrusive than a fingerprint, which requires that one's fingers be smeared with grease and pressed against paper."106 Urine specimens, moreover, are commonly collected and examined for routine medical purposes. Because individuals undergo such tests customarily without objection, the intrusiveness of these tests is slight. ${ }^{107}$

"Rochin v. California, 342 U.S. 165, 172 (1952). For commentators discussing the intrusiveness of various searches, see Note, Analyzing the Reasonableness of Bodily Intrusions, 68 Marquette L.Rev. 130 (1984); Note, Blood Alcohol Analysis and the Fourth Amendment, 1984 Det.C.L.Rev. 1023-38 (1984).

100 Turner, 500 A.2d at 1009.

101 Tucker, 613 F.Supp. at 1129-30; Storms, 600 F.Supp. at 1220.

${ }^{102}$ Shoemaker II, 619 F.Supp. at 1098; Capua, 643 F.Supp. at 1513; American Federation of Government Employees, 651 F.Supp. at 733. Courts typically compare urinalysis to blood tests because the Supreme Court has recognized that the extraction of blood can be a highly invasive procedure which affects an individual's "interests in human dignity and privacy." Schmerber v. California, 384 U.S. 757, 769-70 (1966).

${ }^{103}$ Caruso, 506 N.Y.S.2d at 792; Feliciano, 661 F.Supp. at 586.

104 Allen, 601 F.Supp. at 488; Hampson v. Satran, 319 N.W.2d 796, 800 (N.D. 1982); Mack, 653 F.Supp. at 75; Shoemaker I, 608 F.Supp. at 1158; Amalgamated Transit Union, Local 1277, 663 F.Supp. at 1566.

${ }^{105}$ But see Storms, 600 F.Supp. at 1218, quoting Schmerber, 384 U.S. at 769 (in a sense, if not literally, urinalysis "is an 'intrusion beyond the body's surface" ").

${ }^{106}$ Mack, 653 F.Supp. at 75.

${ }^{107}$ The Schmerber Court gave important weight to the fact blood tests were routinely required in the medical context as an indication such tests can be reasonable. Schmerber, 
For these reasons, courts should view urinalysis as, at most, a minimally intrusive search.

A test's intrusiveness also depends significantly on the manner in which the test is conducted. ${ }^{108}$ The United States Supreme Court suggested guidelines for defining a reasonable test in Schmerber $v$. California. ${ }^{108}$ First, the test must be a reasonable means for establishing the fact sought. ${ }^{110}$ The EMIT tests suggested in $\S 4$ of the Drug Testing Proposal meet this standard by offering 95 percent accuracy in lab tests. Second, the procedure involved in administering the test must be routine or "commonplace" such that it involves "virtually no risk, trauma or pain."11 Giving a urine sample is a routine occurrence which involves no risk of trauma or pain, especially when given in private. Finally, according to Schmerber, a physician should perform the test in a medical environment "according to accepted medical practices."112 However, where a nontechnical procedure is utilized, as in the case of urine collection, "[t]he simplicity of the test makes it unnecessary to have it conducted by a physician."113

Courts have also noted that the procedure's intrusiveness is heightened by the presence of inspectors supervising the tests.114 As one court has suggested, observation of a party during urination "presents an even greater intrusion on privacy than does blood testing." lem. Because accurate tests are possible without official observation, ${ }^{116}$ the government can conduct urinalysis in a way that meets

384 U.S. at 771 n.13.

${ }^{108}$ For example, the Caruso court referred to urination in the presence of another as both "degrading" and "humiliating." Caruso, 506 N.Y.S.2d at 793; see also Tucker v. Dickey, 613 F.Supp. 1124, 1130 (W.D.Wisc. 1985). If an observer is not present, these "degrading" or "humiliating" aspects decrease.

${ }^{108} 384$ U.S. 757 (1966).

110 Id. at 771.

111 Id.

12 Id.

${ }^{113}$ United States v. Smith, 470 F.2d 377, 379 (D.C.Cir. 1972); Weir, 657 F.2d 1005 (reasonable search where FBI agents combed and plucked the defendant's head, beard, and mustache for hair samples); United States v. Bridges, 499 F.2d 179 (7th Cir. 1974) (reasonable search where FBI agents swabbed the defendant's hand in order to ascertain the presence of dynamite particles). EMIT, the initial screening test for drugs, requires no specialized training to administer. See note 11 .

114 See Lovvorn, 647 F.Supp. at 880 n.5; Capua, 643 F.Supp. at 1511; Caruso, 506 N.Y.S.2d at 793.

${ }^{118}$ Caruso, 506 N.Y.S.2d at 793. But see American Federation of Government Employees, 651 F.Supp. at 734 (lack of observation does not appreciably decrease the intrusiveness of the search).

${ }^{116}$ See the Drug Testing Proposal § 3(b). 
the Schmerber guidelines.

2. Governmental Interests Promoted by Urinalysis. Urinalysis promotes numerous fundamental government interests. In considering the "reasonableness" of urinalysis, courts have balanced the intrusiveness of the test against the following government interests: public safety, ${ }^{117}$ employee safety, ${ }^{118}$ national security, ${ }^{118}$ public confidence in the integrity of a government agency, ${ }^{120}$ the ability of the employee to discharge his duties, ${ }^{121}$ and efficiency in the workplace. ${ }^{122}$ In addition, the government's interest in protecting itself from tort liability as a result of safety violations by its employees is substantial since employers are liable for the foreseeable acts of their employees. A court conceivably could find the government liable for acts committed by a government employee while under the influence of drugs. ${ }^{123}$

The most important government interest promoted by urinalysis is public safety. This concern carries special force with regard to positions "such as that of police officer, firefighter, bus driver, or train engineer, where, given the nature of the work, the use of controlled substances would ordinarily pose situations fraught with imminent and grave consequences to public safety."124 Courts have given substantial weight to public safety concerns inherent in these types of occupations when deciding upon the "reasonableness" of urinalysis testing. For example, courts have repeatedly recognized that in the case of a police officer "not only his life, but the lives of the public" rest upon his actions. ${ }^{125}$ " $[B]$ y reason of the fact they carry weapons, drive cars, are engaged in dangerous work, those [police officers] impaired by drug use present a positive danger to others."126

Courts also have considered employee safety and national se-

11: Turner, 500 A.2d at 1008, City of Palm Bay, 475 So.2d at 1326; Bostic, 650 F.Supp. at 250; Suscy, 538 F.2d at 1267; Patchogue-Medford, 505 N.Y.S.2d at 892; Mullholland, 660 F.Supp. at 1570 .

${ }^{118}$ Allen, 601 F. Supp. at 491; McDonell, 809 F.2d at 1307; Mack, 653 F.Supp. at 75; Mullholland, 660 F.Supp. at 1570.

118 Callaway, 518 F.2d at 476; Mack, 653 F.Supp. at 75.

${ }^{220}$ City of Palm Bay, 475 So.2d at 1324; Caruso, 506 N.Y.S.2d at 795; Shoemaker I, 608 F.Supp. at 1158; Bostic, 650 F.Supp. at 250.

${ }_{121}$ Bostic, 650 F.Supp. at 250; City of Palm Bay, 475 So.2d at 1324; Allen, 601 F.Supp. at 491; Turner, 500 A.2d at 1008; Feliciano, 661 F.Supp. at 589; Raab, 816 F.2d at 178.

${ }^{122}$ Amalgamated Transit Union, 663 F.Supp. at 1568.

${ }^{123}$ Ira S. Bushey \& Sons, Inc. v. United States, 398 F.2d 167 (2d Cir. 1968).

124 Patchogue-Medford, 505 N.Y.S.2d at 891.

${ }_{125}$ Turner, 500 A.2d at 1008; see also City of Palm Bay, 475 So.2d at 1324; Bostic, 650 F.Supp. at 250.

${ }^{228}$ Caruso, 506 N.Y.S.2d at 796. 
curity as factors to weigh against intrusiveness when determining the reasonableness of urinalysis. In regard to both of these concerns, one court has noted that the government has a compelling interest in testing where "drug use by an [FBI] agent could affect the success of an operation implicating important national security law enforcement objectives and could pose risk of injury to other agents working with him." ${ }^{127}$ Like public safety considerations, employee safety and national security considerations obviously vary with the government employee's occupation and can be nonexistent in some cases.

The Drug Testing Proposal recognizes that the federal government's interest in testing employees varies with the employee's responsibilities. Section 2 of the Drug Testing Proposal allows the FDTA to determine the agencies or sectors that will be tested. Given the limited resources of the government, the FDTA probably will focus only on those agencies that exhibit an overriding need for testing. In granting the FDTA this discretion, the Drug Testing Proposal ensures that the government will test only those employees or applicants whom it is efficient or important to test.

The government's interest in maintaining public confidence in the integrity of government employees likewise is compelling. ${ }^{128} \mathrm{~A}$ police officer's use of illegal substances, for example, would undermine public "confidence and respect."129 Public employees using drugs while on duty seriously hinder the credibility of the government. Moreover, at least one court has recognized that the government has "a legitimate, if lesser, interest in preventing such offduty conduct."130

Another factor that courts have balanced against the intrusiveness of urinalysis is the government's interest in overseeing an employee's "performance of his duties." The seminal case in this emerging body of law, Allen $v$. City of Marietta, ${ }^{131}$ upheld a government testing program as reasonable because the government's

${ }^{127}$ Mack, 653 F.Supp. at 75.

${ }^{128}$ See, e.g., Caruso, 506 N.Y.S.2d at 796 (Urinalysis is legitimate because "the government has a recognized and a legitimate interest in maintaining [employee] integrity" in certain occupations).

${ }^{128}$ City of Palm Bay, 475 So.2d at 1324; Caruso, 506 N.Y.S.2d at 796; Biehunik, 441 F.2d at 230; O'Brien, 544 F.2d at 546; Barry, 712 F.2d at 1560.

The public confidence aspect is arguably less applicable in the case of some government employees although other government interests such as efficiency and employee performance may override these differences. The difference between the importance of the public's confidence in a policeman and a postal clerk is pronounced and must be taken into account.

${ }^{130}$ Bostic, 650 F.Supp. at 250.

132601 F.Supp. 482 (N.D.Ga. 1985). 
interest in overseeing its employees' performance outweighed the intrusiveness of urinalysis. The analysis in the Allen decision has broad implications. Unlike some interests that vary or become nonexistent depending upon an individual's occupation, the government's interest in overseeing its employees' performance remains relatively constant. Whether a government employee is a police officer or postal clerk, the government has an important interest, just as private employers do, in overseeing its workers' performance. ${ }^{132}$

3. Completing the Balancing Test. One must balance the intrusiveness of the test against the government interest at stake to determine the "reasonableness" of a government drug testing program. Courts in the urinalysis context, with some exceptions, ${ }^{133}$ have found government urine testing programs unreasonable. ${ }^{134}$ Many courts have found that the intrusiveness of testing outweighs the government interest promoted by such tests. Are such conclusions correct?

As suggested above, urinalysis is a test of minimal intrusiveness. Although the government's interest in testing varies among occupations, in general it seems to outweigh urinalysis' intrusiveness. In some occupations involving public safety, employee safety, or national security, the government's interest easily will overcome this minimal intrusion. For example, air traffic controllers, public transit employees, police officers, firefighters, and military personnel all perform tasks for which it is necessary-either for public safety, the safety of other employees, or national security-that they perform their duties responsibly. In other occupations, however, public safety, employee safety, or national security rationales do not apply.

Consider, for example, a post office employee. Except in unusual circumstances, public safety is not threatened by his erratic behavior; his actions typically do not threaten the safety of others or undermine national security. However, independent factors sug-

${ }^{232}$ One court has recognized a particular government interest in "workplace efficiency." See Amalgamated Transit Union, 663 F.Supp. at 1569.

${ }^{133}$ Allen, 601 F.Supp. at 491; Shoemaker III, 795 F.2d at 1143; McDonell, 809 F.2d at 1308; Suscy, 538 F.2d at 1267; Callaway, 518 F.2d at 477; Turner, 500 A.2d at 1009; Raab, 816 F.2d at 182; White, No. CIV-1-87-187, slip op. at 4 (cited in note 38); Mullholland, 660 F.Supp. at 1570; Rushton, 653 F.Supp. at 1525.

${ }^{134}$ For a sampling of such cases, see Capua, 643 F.Supp. at 1520; Caruso, 506 N.Y.S.2d at 798; American Federation of Government Employees, 651 F.Supp. at 732; Lovvorn, 647 F.Supp. at 883; Amalgamated Transit Union, 663 F.Supp. at 1569; Feliciano, 661 F.Supp. at 583. 
gest that urinalysis is reasonable. The government's interest in assuring the public confidence in the post office is an example of one such interest. Likewise, the government has a legitimate interest in the post office employee's efficiency. If a number of employees were unable to perform their jobs efficiently, such conduct might impair the agency's ability to fulfill its statutory obligations. "[W] here an employee's misconduct is contrary to the agency's mission, the agency need not present proof of a direct effect on the employee's job performance" to remove the employee under current law. ${ }^{136}$

Arguments downplaying the importance of these interests are unpersuasive. Some argue that urinalysis is not necessary to monitor an employee's job performance. While in some cases an employee's drug use will manifest itself through the employee's absences, tardiness, and errors, other situations exist where supervisors cannot readily discover employee errors. Where such discrepancies could prove extremely costly, ${ }^{136}$ drug testing offers an effective means of preventing significant governmental losses.

Courts have suggested that many of the government interests advanced above prove too much. ${ }^{137}$ One might contend, for example, that the government integrity rationale posits no limit to search powers. This argument, however, ignores the other half of the "reasonableness" test: the intrusiveness of the search. While the government could justify a minimally intrusive search like urinalysis by pointing to relatively weak government interests (for example, public confidence in government employees), the government could not justify a highly intrusive search (for instance, involving an employee's home), by pointing to these same values. The government integrity rationale thus need not entail wholesale approval of all government searches.

\section{Fourth Amendment Procedural Requirements}

Opponents of the Drug Testing Proposal might maintain that

${ }^{135}$ Allrod v. Department of Health and Human Services, 786 F.2d 1128, 1131 (Fed.Cir. 1986). See also Wild v. United States, 692 F.2d 1129, 1133 (7th Cir. 1982). This argument for urinalysis does not exist in the private sector. Government agencies are required to perform certain duties by law. By contrast, the objectives of private employers do not depend on statutory specifications.

${ }^{133}$ For example, suppose the government obtains benefits of $\$ 100$ from each of its 2.8 million employees. If drug use causes a 10 percent reduction in the performance of 25 percent of these employees, the total government loss is a substantial $\$ 7$ million.

${ }^{137}$ See, e.g., American Federation of Government Employees, 651 F.Supp. at 735; McDonell, 612 F.Supp. at 1131. 
government drug testing violates fourth amendment strictures against warrantless searches. Ordinarily, the government must conduct its searches pursuant to warrants approved by a neutral and detached magistrate and based upon a "probable cause"138 belief that the particular party to be searched has violated the law. ${ }^{\mathbf{1 3 9}}$

Although probable cause is the usual standard for issuance of a warrant, courts have accepted a lesser standard in some circumstances. ${ }^{140}$ For example, in the urinalysis context, many courts have found that the proper standard of belief is one of reasonable suspicion $^{141}$ - a lower standard than probable cause. ${ }^{142}$

Likewise, while warrants are generally required to conduct constitutional searches, warrantless searches are not per se unconstitutional. Indeed, the Supreme Court has identified certain categories of exceptions to the fourth amendment warrant requirement. Apart from these exceptions, the Court has held that random searches not conducted pursuant to a warrant may be constitutional in certain circumstances. This subsection first will argue that urinalysis pursuant to the Drug Testing Proposal falls within two of the recognized exceptions to the warrant requirement. It then will demonstrate that the case law upholding random warrantless searches supports the Drug Testing Proposal.

1. Warrant Requirement Exceptions. Three traditional exceptions to the warrant requirement exist. First, a warrant is not required to frisk a suspect in exigent circumstances: for instance, where an immediate danger to government officials or the commu-

${ }^{138}$ Public officials have probable cause to search "where 'the facts and circumstances within their knowledge and of which they had reasonably trustworthy information [are] sufficient in themselves to warrant a man of reasonable caution in the belief' that a criminal offense had occurred." T.L.O., 105 S.Ct. at 755 (Brennan dissenting in part), quoting Carroll v. United States, 267 U.S. 132, 162 (1925).

139 See Coolidge v. New Hampshire, 403 U.S. 443, 449-51 (1971).

${ }^{140}$ See Camara v. Municipal Court of the City and County of San Francisco, 387 U.S. 523 (1967) (allowing warrantless building codes inspection pursuant to "reasonable . . . administrative standards"); Terry v. Ohio, 392 U.S. 1, 27 (1968)(police officer may, without a warrant, conduct a pat-down "stop-and-frisk" search based on probable cause); Sec. \& Law Enforcement Emp. Dist. Council 82 v. Carey, 737 F.2d 187, 203 (2d Cir. 1984)(reasonable suspicion standard governs warrantless strip-searches of corrections officers within prisons).

111 White, No. CIV-1-87-187, slip op. at 6 (cited in note 38); Feliciano, 661 F.Supp. at 587; Fraternal Order of Police, Newark Lodge No. 12, 524 A.2d 430, 437; Amalgamated Transit Union, Local 1277, 663 F.Supp. at 1568; Lovvorn, 647 F.Supp. at 882; Capua, 643 F.Supp. at 1517; City of Palm Bay, 475 So.2d at 1325; Turner, 500 A.2d at 1011; Caruso, 506 N.Y.S.2d at 799.

${ }^{142}$ The reasonable suspicion test requires government officials to "point to specific objective facts and rational inferences that they are entitled to draw from these facts in light of their experience." City of Palm Bay, 475 So.2d at 1326. 
nity exists. ${ }^{143}$ Second, officials need not have a warrant where the suspect may destroy evidence or vanish while a warrant is being obtained. ${ }^{144}$ Third, government officials need not obtain a warrant to conduct an administrative search. ${ }^{145}$ Finally, in addition to these traditional warrant exceptions, a federal district court has upheld the constitutionality of warrantless searches performed by the government acting in its proprietary capacity. ${ }^{146}$ Arguably, both the administrative search exception and the proprietary capacity exception exempt the government from the fourth amendment's warrant requirements when it conducts urinalysis tests pursuant to the Drug Testing Proposal. ${ }^{147}$

a. Administrative Search Exception and Regulated Industries. The Supreme Court first ruled on the administrative search exception when holding that housing inspectors are exempt from fourth amendment warrant requirements because of the unique character of their job. ${ }^{148}$ Since this decision, courts have extended the administrative search exception to uphold warrantless blanket searches in a number of instances, ${ }^{149}$ including blanket searches at the premises of certain heavily regulated industries. ${ }^{150}$ Recently,

${ }^{143}$ Terry, 392 U.S. at 20.

${ }^{144}$ Schmerber, 384 U.S. at 770-71.

${ }^{145}$ Donovan v. Dewey, 452 U.S. 594 (1981). Administrative searches occur primarily in "pervasively regulated industries" which have long been subject to government supervision and regulation. Marshall v. Barlow's, Inc., 436 U.S. 307, 313 (1978).

${ }^{148}$ Allen, 601 F.Supp. at 491.

${ }^{167}$ The exigent circumstances exception to the warrant requirement is not applicable to government employee or applicant urinalysis. No "immediate" danger exists to other government officials or to the community at large as a result of employee drug use.

The dissipating exception argument is also weak. Drugs will dissipate in the body over time. See Ewing v. State, 310 N.E.2d 571 (Ind.Ct.App. 1974) (noting that drugs like alcohol diminish in the blood over time). However, this exception is not relevant in the present context because the Drug Testing Proposal utilizes random testing. The exception applies only where the evidence sought to be preserved clearly exists. Schmerber, 384 U.S. at 768-69 (exception applied because police had reason to believe that subject was intoxicated). In a random program, one cannot predict whether the randomly selected individual is a drug user; thus, one has no particularized reason to believe that there is a danger of dissipation.

${ }^{148}$ Camara, 387 U.S. 523. The Court justified the exception because of the public health interest in housing inspection and the inability of housing inspectors to identify dangerous conditions from outside a building.

${ }_{148}$ See, e.g., United States v. Martinez-Fuerte, 428 U.S. 543, 545 (1976)(border areas); Davis, 482 F.2d at 912 (airport departure gates); Downing v. Kunzig, 454 F.2d 1230, 1232-33 (6th Cir. 1972)(courthouse doors); Barrett v. Kunzig, 331 F.Supp. 266, 274 (M.D.Tenn. 1971)(same).

${ }^{150}$ See, e.g., Donovan, 452 U.S. 594 (mines and stone quarries); United States v. Biswell, 406 U.S. 311 (1972)(gun dealers). Moreover, in Ortega, 107 S.Ct. at 1504, the plurality opinion suggested that the administrative search exception might be applicable to testing of government employees. The Court found the warrant and probable cause requirements imposed an insurmountable burden on government employers engaged in work-related 
the Supreme Court has justified government administrative searches of pervasively regulated industries for two reasons. First, the Court has argued that the government's interest in these searches is great, as evidenced by the government's decision to regulate the industry in the first place. ${ }^{101}$. Second, the Court has argued that corresponding knowledge and voluntary acceptance of the regulatory interest ${ }^{162}$ reduces an individual's expectation of privacy. ${ }^{153}$

In the urinalysis context, the Second Circuit has upheld the random testing of jockeys based on this rationale. ${ }^{154}$ Finding a strong state interest in preserving public confidence in the racing industry (manifested in state regulation of that industry) and also a reduced expectation of privacy for jockeys (due to the advance notice provided by such pervasive regulation), the Second Circuit held that urine testing does not violate the Fourth Amendment. ${ }^{155}$ Does the "pervasive regulation" rationale extend to drug testing for public employees? Courts disagree on this issue. ${ }^{186}$

The Drug Testing Proposal outlined herein seeks justification from both of the two factors behind the Second Circuit's view. As noted earlier, the government retains an interest in maintaining public confidence in its employees. In addition, the nature of public employment and the advance notice provisions of the Drug Testing Proposal serve to reduce employee's legitimate expectations of privacy in this context. The Proposal thus may come within the administrative search exception dealing with regulated industries. After all, what can be more pervasively regulated than the government itself?

searches, and substituted a standard of reasonableness under all circumstances.

${ }^{151}$ See Donovan, 452 U.S. at 606.

${ }_{152}$ Marshall, 436 U.S. at 313 (an entrepreneur embarking upon such a business volunta-

rily chooses to subject himself to a full arsenal of government regulation).

${ }^{18 s}$ See, e.g., Donovan, 452 U.S. at 600 :

A warrant may not be constitutionally required when Congress has reasonably determined that warrantless searches are necessary to further a regulatory scheme and the federal regulatory presence is sufficiently comprehensive and defined that the owner of commercial property cannot help but be aware that his property will be subject to periodic inspections undertaken for specific purposes.

${ }^{154}$ Shoemaker III, 795 F.2d at 1142.

18s Id. at 1142-43.

${ }^{156}$ Some courts have found the pervasive regulation exception does not apply in the context of government urinalysis testing. See, e.g., Capua, 643 F.Supp. at 1519; Caruso, 506 N.Y.S.2d at 798; American Federation of Government Employees, 651 F.Supp. at 734; Fraternal Order of Police, 524 A.2d at 435; Feliciano, 661 F.Supp. at 591. But see Raab, 816 F.2d at 179 (government employee testing is analogous to pervasive regulation exceptions); Rushton, 653 F.Supp. at 1524-25 (same). 
b. Government Action in Its Proprietary Capacity as an Employer Exception. A recent emerging exception to the warrant requirement focuses on the government's ability to "investigate potential misconduct relevant to the employee's performance of his duties." 157 This exception maintains that public and private employers should have the same investigatory rights in regard to their employees. ${ }^{158}$

Many courts have rejected such an exception to the warrant requirement. ${ }^{159}$ One court, objecting to the notion that one should regard public employees as similar to private employees, stated that "it will be a dark day indeed when the United States government finds it appropriate to abandon the strictures of the Constitution in favor of a less burdensome 'private-sector' set of rules that can allow for infringement of constitutional rights." 160 In the urinalysis context, only a few courts have adopted this exception to the fourth amendment warrant requirements. ${ }^{161}$ Nevertheless, the exception is a plausible one in light of contemporary conditions.

To treat public employees differently from private employees in the urinalysis context is to place the government as an employer at a disadvantage compared with private employers. This effect can be substantial in situations where the government competes with private employers: for example, Federal Express versus Next Day Mail or private versus public education. There, the costs of drug use among its employees makes the government an inefficient competitor vis-a-vis private business.

More importantly, the modern administrative state posits a role for the federal government that frequently entails exclusive control over vast regulatory responsibilities-a task undertaken by a teeming bureaucracy of federal employees. Under such conditions, a jurisprudence that bars circumscribed assertions of control by the government in its capacity as employer may jeopardize the effective fulfillment of tasks for which there exists no alternative institution. Taking these factors into account, application of the employer exception to government drug testing programs seems plausible.

${ }^{157}$ Allen, 601 F.Supp. at 491.

${ }^{188}$ Allen, 601 F.Supp. at 491; Patchogue-Medford, 505 N.Y.S.2d at 893. See also Collins, 349 F.2d at 868; Bunkers, 521 F.2d at 1220; United States v. Grisby, 335 F.2d 652 (9th Cir. 1964); Donato, 269 F.Supp, at 924.

${ }^{158}$ See, e.g., Capua, 643 F.Supp at 1519; American Federation of Government Employees, 651 F.Supp. at 737.

${ }^{160}$ American Federation of Government Employees, 651 F.Supp. at 737.

${ }^{182}$ Patchogue-Medford, 505 N.Y.S.2d at 895; Bostic, 650 F.Supp. at 250. 
2. The Random Nature of the Drug Testing Proposal. Completely apart from exceptions to the warrant requirement, courts have upheld the constitutionality of random searches not conducted pursuant to search warrants. ${ }^{162}$ Courts have consistently recognized that random searches and seizures violate the fourth amendment only when the government leaves the selection of targets solely in the hands of a field officer. ${ }^{163}$ If the government implements indiscriminate screening procedures and the urine testing of government employees is not "subject to the discretion of the official in the field," such tests can pass constitutional scrutiny. ${ }^{164}$ In two contexts, courts have upheld random searches and relaxed the probable cause and reasonable suspicion standards. In both situations, courts have justified their holdings by emphasizing that the administrative scheme at issue left no discretion in the hands of officers in the field.

First, courts have upheld random searches in the airport magnetometer situation. Here, the testing procedure vests no discretion in the administrator because every passenger must pass through a magnetometer to board a plane. Pointing to this lack of discretion, courts have upheld these random tests as constitutional. ${ }^{185}$ Only one condition attaches to such searches: each prospective passenger must retain the right to leave rather than submit to the search. ${ }^{168}$

Courts also have upheld the constitutionality of random searches in which the police have established roadblocks to check for valid drivers' licenses ${ }^{\mathbf{1 6 7}}$ or to determine the residency of individuals entering the United States. ${ }^{168}$ In Delaware v. Prouse ${ }^{169}$ for example, the Supreme Court found that driver's license stops at the random discretion of police officers were unconstitutional. Such a practice vested too much discretion in the hands of officers

${ }^{162}$ For cases accepting random testing, see Mullholland, 660 F.Supp. at 1569; Rushton, 653 F.Supp. at 1525; Raab, 816 F.2d at 182; Mack, 653 F.Supp. at 70; Callaway, 518 F.2d at 477; McDonell, 809 F.2d at 1308.

${ }^{163}$ Delaware v. Prouse, 440 U.S. 648, 661 (1979); United States v. Brigoni-Ponce, 422 U.S. 873, 882-84 (1975). The notion that programs leaving discretion in the hands of government officials in the field violates the fourth amendment transforms the fourth amendment into an anti-discrimination amendment. See John Hart Ely, Democracy and Distrust 96-97 (1977).

${ }^{104}$ Camara, 387 U.S. at 532; Martinez-Fuerte, 428 U.S. at 566-67.

${ }^{20 s}$ Davis, 482 F.2d at 910. Here, the court also focused on the important government interest in preventing hijacking and the minimal intrusiveness of these tests.

${ }^{168}$ Id. at $910-11$.

167 Delaware v. Prouse, 440 U.S. 648, 663 (1979).

${ }^{168}$ Martinez-Fuerte, 428 U.S. at, 564-66.

${ }^{169}$ Prouse, 440 U.S. at 661. 
at the scene of the search. But the Prouse Court went on to add that police roadblocks are constitutionally permissible if they "do not involve the unconstrained exercise of discretion," noting that "[q]uestioning of all oncoming traffic at roadblock-type stops is one possible" type of constitutional search. ${ }^{170}$

Some courts upholding government employee drug testing have stressed that the random nature of the drug test solves fourth amendment concerns. ${ }^{171}$ One court noted that officer discretion in selecting those to test "presented the potential for abuse" and suggested that "computer-guided random selection procedures" would be less problematic. ${ }^{172}$ Another court noted that the "unbridled discretion" of the government employer conducting such tests was "contrary to the very tenet of the Fourth Amendment."173

The Drug Testing Proposal outlines a scheme that passes constitutional scrutiny because the proposal does not vest discretion in drug test administrators. Section 2 of the Drug Testing Proposal, calling for an independent agency to monitor the testing and for random testing, ensures that no employer bias against an employee will manifest itself in arbitrary tests. Similarly, $\S 3$ mandates that the Drug Testing Agency officials have no discretion about which individuals to test. The agency must promulgate some random, neutral regulation that will ensure fairness in testing.

\section{Due Process Procedural Concerns}

Thus far, this comment has concentrated on the fourth amendment implications of required employee drug testing. In an effort to illuminate the rationale behind the Drug Testing Proposal's evaluation and termination requirements, contained in $\S 5$ of the proposal, this section considers a problem beyond the scope of the fourth amendment: if an employee tests positive for drugs, what remedies are available to an employer?

${ }^{170}$ Id. at 663 (emphasis added). In concurrence, Justice Blackmun noted "that the Court's reservation also includes other not purely random stops." Id. at 670 . It is unnecessary for a checkpoint stop to stop every car in order to be systematic. Officers merely must follow some pattern-for example, every third car-minimizing their discretion in choosing whether to stop any particular car.

${ }^{171}$ For courts accepting random urinalysis, see, e.g., Rushton, 653 F.Supp. at 1525; McDonell, 809 F.2d at 1308; Shoemaker III, 795 F.2d at 1143.

172 Storms, 600 F.Supp. at 1223.

${ }^{173}$ Capua, 643 F.Supp. at 1515; see also Lovvorn, 647 F.Supp. at 881 (failing to limit official-in-the-field discretion makes the test constitutionally impermissible). 
A. Employment as a Property Right

The Constitution does not create property interests. Rather, "they are created and their dimensions are defined by existing rules or understandings that stem from an independent source such as state law. . . ."174 A program of government drug testing might implicate two types of property rights. First, if a federal, state, or local statute provides that certain government employees are entitled to retain their position during good behavior and efficient service and the statute also provides that the government may terminate such employees only with good cause, then the statute vests such persons with a property right in their employment. ${ }^{175}$ Courts have applied this type of reasoning in the urinalysis context. ${ }^{176}$

An individual may also have a property interest in his good name and reputation when a public employer publicly discloses the reasons for an employee's discharge and those reasons are false. ${ }^{177}$ In the urinalysis context, one court has noted that where no "provisions [were] made to protect the confidentiality interests" of government employees, an individual's property interest in his reputation is implicated. ${ }^{178}$ In the present context, however, this argument is weak since the Drug Testing Proposal forbids public disclosure of drug test results.

\section{B. Due Process Termination Requirements}

Because a non-probationary employee enjoys a property interest in his job in certain circumstances, the government must terminate such an employee subject to due process requirements. ${ }^{179}$ Under the due process clause, a deprivation of life, liberty, or property must "be preceded by notice and opportunity for hearing appropriate to the nature of the case." 180 Adequate notice requires

174 Cleveland Board of Education v. Loudermill, 105 S.Ct. 1487, 1491 (1985); Board of Regents v. Roth, 408 U.S. 564, 577 (1972); see also Paul v. Davis, 424 U.S. 693, 709 (1976).

${ }^{178}$ Loudermill, 105 S.Ct. at 1491.

178 Capua, 653 F.Supp. at 1520; Bostic, 650 F.Supp. at 251; Lovvorn, 647 F.Supp. at 883.

177 Bishop v. Wood, 426 U.S. 341, 348 (1976); Hester v. City of Milledgeville, 598 F.Supp. 1456, 1473 (M.D.Ga. 1984).

${ }_{178}$ Capua, 643 F.Supp. at 1520.

178 Loudermill, 105 S.Ct. at 1493-94. The fourteenth amendment provides in pertinent part: "nor shall any State deprive any person of life, liberty, or property, without due process of law;" U.S.Const. amend. XIV, \& 1 . The fifth amendment puts a similar restraint upon the national government: "No person shall . . . be deprived of life, liberty, or property, without due process of law . . ." U.S.Const. amend. V.

${ }^{180}$ Mullane v. Central Hanover Tr. Co., 339 U.S. 306, 313 (1950). See also Boddie v. 
only that the government provide the tenured public employee with oral or written notice of the charges against him. ${ }^{181}$ Whereas the formality and procedural prerequisites for a "fair hearing" vary depending on the importance of the interests at stake, ${ }^{182}$ a number of widely accepted procedural safeguards exist in the public employment context. ${ }^{183}$ First, the government must advise the employee "of the cause or causes for his termination in sufficient detail to enable him fairly to show any error that may exist."184 Second, the government must advise the employee "of the names and the nature of the testimony of witnesses against him."185 Third, the government must accord the employee "a meaningful opportunity to be heard in his own defense."186 Finally, the employee's hearing should be before a tribunal "that both possesses some expertise [in the occupation of the employee] and has an apparent impartiality toward the charges." 187 The government, moreover, must grant the employee some kind of hearing before discharging the employee. ${ }^{188}$ This hearing can be "something less" than a full evidentiary hearing. ${ }^{188}$

In addition to these due process considerations, federal statutes impose limits on the government's ability to terminate its employees. The Civil Service Reform Act of 1978, § 1513(a), prohibits the federal government from dismissing federal employees unless the government can show that such a dismissal promotes "the efficiency of the service."190 The case law is inconclusive on the question of whether drug use is an action that can result in termination under this procedure. ${ }^{191}$ Nonetheless, one can conclude, as did the

\footnotetext{
Connecticut, 401 U.S. 371, 374-75 (1971).

181 Loudermill, 105 S.Ct. at 1495; see also Arnett v. Kennedy, 416 U.S. 134, 170-71 (1974).

${ }^{182}$ Roth, 408 U.S. at 570-71.

${ }^{183}$ For cases discussing due process requirements of urinalysis testing see Lovvorn, 647 F.Supp. at 883; Jones, 628 F.Supp. at 1507; Bostic, 650 F.Supp. at 251.

184 Ferguson v. Thomas, 430 F.2d 852, 856 (5th Cir. 1970). Regarding this requirement, the Fifth Circuit has noted in Banks v. FAA, 687 F.2d 92, 96 (5th Cir. 1982), that due process requires the government to grant employees an opportunity to test, on their own behalf, their voluntarily submitted urine samples.

${ }^{18 s}$ Ferguson, 430 F.2d at 856.

${ }^{188}$ Id.

${ }^{187}$ Id.

${ }^{188}$ Loudermill, 105 S.Ct. at 1493. Loudermill supports its requirement of a presuspen-
} sion hearing conclusion by finding that employee interests outweigh government interests in this context. Id. at 1494-95.

${ }^{188}$ Mathews v. Eldridge, 424 U.S. 319, 343 (1976).

1805 U.S.C. $\S 7513(\mathrm{a})$ (1982).

${ }^{102}$ Compare Young v. Hampton, 568 F.2d 1253, 1266 (7th Cir. 1977)(unlawful possession of controlled substance had no detrimental effect on the efficiency of the service and 
Second Circuit in Borsari v. F.A.A. ${ }^{192}$ that where an employee's misconduct-on or off the job-"conflicts with the mission of the agency, dismissal without proof of a direct effect on the individual's job performance is permissible under the 'efficiency of the service' standard." Thus, the Civil Service Reform Act of 1978 does not require the government to demonstrate that an employee's drug use directly effects his job performance. Rather, the government must merely show that the employee's drug use conflicts with the mission of his governmental employer.

The 1978 Amendments to the Rehabilitation Act of 1973 also explicitly recognize that the denial of employment opportunities on the basis of alcohol or drug use is justified only under limited circumstances. The Amendments note that the term "handicapped individual" does "not include any individual who is an alcoholic or drug abuser whose current use of alcohol or drug abuse, would constitute a direct threat to the property or the safety of others."193 However, by negative inference, this Amendment prohibits discrimination against individuals who are able to perform a job. ${ }^{194}$ The Act thus protects former drug addicts and alcoholics currently under control. ${ }^{198}$ As the Act stands, the government may remove the employee only if that person is clearly incapable of performing his job.

Courts, in interpreting the Rehabilitation Act, have held that the government must attempt to accommodate an employee's substance abuse problems. Recently, for example, a federal court overturned the discharge of an alcoholic employee of the Defense Department who had been repeatedly absent from work. ${ }^{196}$ Prior to his termination, the employee had undergone treatment for alcoholism. Following the treatment, he was again absent without authorization on several occasions, although the later absences were unrelated to his alcoholic condition. In discharging him, the department considered his pre-treatment and post-treatment absences cumulatively. The court ruled that the department should

thus dismissal not justified), with Borasari v. F.A.A., 699 F.2d 106, 110-11 (2d Cir. 1983)(drug use conflicts with agency's mission and dismissal is permissible).

192699 F.2d 106 (2d Cir. 1983). See also Masino v. United States, 589 F.2d 1048 (Ct.Cl. 1978)(upholding discharge of a customs officer following his off-duty use of marijuana); Giles v. United States, 553 F.2d 647 (Ct.Cl. 1977)(IRS agent dismissed for failing to file timely tax returns); Wroblaski v. Hampton, 528 F.2d 852 (7th Cir. 1976) (Immigration and Naturalization Service official removed for employing illegal aliens in his home).

19329 U.S.C. $\$ \S 701-96,706(7)(B)$ (1982).

196 See 124 Cong.Rec. 37,509 (Oct. 14, 1978)(remarks of Sen. Williams).

105 See Davis v. Bucher, 451 F.Supp. 791, 796 (E.D.Pa. 1978).

${ }^{198}$ Walker v. Weinberger, 600 F.Supp. 757, 763 (D.D.C. 1985). 
have forgiven, and not considered at all, the absences that predated the employee's treatment for alcoholism. ${ }^{197}$

Government urinalysis programs that involve employee termination must incorporate the procedural requirements outlined above. Section 5 of the Drug Testing Proposal takes into account these requirements. The Drug Testing Proposal makes every effort to rehabilitate an employee rather than terminate him. However, if termination is necessary, $\S 5$ provides a comprehensive scheme that ensures an employee is terminated in accordance with due process of law.

\section{CONCLUSION}

Drug use is a pervasive problem in American society. The effects of such use make it a public and not a private crisis. Random federal government drug testing of federal employees or federal employment applicants is a partial solution to this difficulty. Despite assertions to the contrary, such testing does not ignore "the principle as old as the common law" that "the individual shall have full protection in person and property."198 Rather, such testing personifies the suggestion that from time to time it is necessary for courts to "define anew" the exact nature and extent of "an individual's protection in his person." 199 Drug use requires the courts to "define anew" an individual's fourth amendment protection. A properly administered random urinalysis program can pass constitutional scrutiny.

${ }^{198}$ Samuel D. Warren and Louis D. Brandeis, The Right to Privacy, 4 Harv.L.Rev. 193 (1890).

180 Id. 